\title{
Purwarupa Sistem Integrasi Metadata Foto Udara Dengan Data Sistem ADAHRS
}

\author{
Raden Sumiharto $^{* 1}$, Intan Nur Fadliilah ${ }^{2}$ \\ ${ }^{1}$ Departemen Ilmu Komputer dan Elektronika, FMIPA UGM, Yogyakarta \\ ${ }^{2}$ Prodi Elektronika dan Instrumentasi, Jurusan Ilmu Komputer dan Elektronika, FMIPA UGM

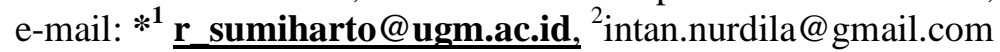

\begin{abstract}
Abstrak
Pada penelitian ini telah diimplementasikan sebuah sistem integrasi metadata foto udara dengan data sistem ADAHRS. Pengambilan foto dan data ADAHRS dilakukan secara bersamaan menggunakan kamera dan perangkat ADAHRS yang dipasang pada UAV. Data ADAHRS yang diambil meliputi tanggal, waktu, kecepatan udara, GPS latitude, GPS longitude, ketinggian, suhu, tekanan udara, roll, pitch, dan yaw.

Metode yang digunakan sistem ini meliputi konfigurasi custom tag, ekstraksi metadata foto, sinkronisasi dan integrasi data ADAHRS dengan metadata foto. Proses konfigurasi, ekstraksi dan integrasi dilakukan menggunakan ExifTool. Datestamp dan timestamp metadata foto dan data ADAHRS dijadikan sebagai parameter penggabungan data proses sinkronisasi.

Uji coba sistem dilakukan dengan pengujian pengaruh variasi resolusi dan jumlah foto terhadap lama waktu keseluruhan proses sistem. Sistem ini mampu mengintegrasikan data ADAHRS pada resolusi foto, yakni 230 piksel x 1536 piksel, 1920 piksel x 1080 piksel, 1280 piksel $x 720$ piksel, dan 848 piksel $x 480$ piksel. Total rerata waktu pemrosesan sistem pada pengujian tersebut adalah 3,936 detik untuk 100 foto, 7,454 detik untuk 200 foto, 11,156 detik untuk 300 buah foto, 14,740 detik untuk 400 foto dan 18,460 detik untuk 500 foto. Sistem ini mampu membuat backup file dari file foto yang berhasil diperbarui metadatanya dan menjaga keaslian metadata foto.
\end{abstract}

Kata kunci- ExifTool, GPS

\section{Abstract}

This research was done by implementing aerial photographs metadata integrated system with ADAHRS data system. Photos and ADAHRS data were taken along using the camera and ADAHRS devices were installed on UAV. Data were taken from ADAHRS consisted of date, time, air speed, GPS latitude-longitude, altitude, temperature, air pressure, roll, pitch, and yaw.

The method in the system included custom tag configuration, extracted metadata, the synchronisation and integrated data between ADAHRS and photo metadata. Configuration, extraction and integration process were done using ExifTool. Datestamp and timestamp in photo metadata and ADAHRS data were used as a parameter of integrating data on synchronisation.

The systematical experiment was done by test on the effect of image resolution and number of photos to the duration of the whole process. This system was able to integrate ADAHRS data from image resolution, were 230 pixels x 1536 pixels, 1920 pixels $x 1080$ pixels, 1280 pixels $x 720$ pixels, and 848 pixels and 480 pixels. Amount of time average of process were 3,936 seconds/100 photos, 7,454 seconds/200 photos, 11,156 second/300 photos, 14,740 seconds/400 photos, and 18,460 seconds/500 photos. This system can be able to make a backup from extended version and retain the originality of photo metadata.

Keywords-ExifTool, GPS 


\section{PENDAHULUAN}

Ceiring berkembangnya teknologi kedirgantaraan Indonesia, pemetaan wilayah kini dapat - dilakukan menggunakan pemetaan foto udara dengan menggunakan pesawat tanpa awak atau yang dikenal sebagai Unmanned Air Vehicle (UAV). Walau begitu, teknologi tersebut masih dirasa kurang efisien, mengingat data-data yang dibutuhkan tidak secara otomatis tersimpan di metadata foto, melainkan hanya ditampilkan di Ground Control Station atau tersimpan dalam suatu media penyimpanan. Sehingga perlu dilakukan pencatatan atan pencocokan data secara manual.

Menurut Susilawati[1], metadata merupakan data terstruktur yang menjelaskan karakteristik sebuah data yang memiliki informasi tertentu dan dibuat dengan tujuan mempermudah identifikasi, pencarian, penilaian maupun manajemen pengelolaan data terkait. Metadata foto pada umumnya hanya berisikan atribut gambar atau foto digital, seperti informasi mengenai tanggal dan waktu pengambilan citra, jenis dan pengaturan kamera yang digunakan serta format dan ukuran citra [2]. Padahal, data-data lingkungan seperti ketinggian, koordinat posisi, kecepatan udara, tekanan udara dan suhu pada saat pengambilan foto juga diperlukan dalam melakukan pengamatan foto udara. Selain itu, data perilaku pesawat juga penting untuk mengetahui bagaimana keadaan pesawat pada saat melakukan pengamatan dan pengambilan data.

Penelitian mengenai metadata telah dilakukan [3], [4], [5] , [6]. Penelitian metadata yang dilakukan oleh Ireene dkk. [3] dan Sutriya [4] dengan menggunakan file grafik sebagai referensinya, untuk melakukan penggabungan metadata ke dalam file grafik serta menghindari kesalahan input data ke dalam database. Berbeda dengan kedua penelitian sebelumnya, Li-Gu dkk. [5] menggunakan metadata pada file digital untuk membuat sistem yang mampu meningkatkan pencarian maupun navigasi . Sedangkan Kakar [6] membuat suatu sistem yang mampu membuktikan metadata suatu citra dengan memanfaatkan data geolokasi dan estimasi arah matahari.

Melihat pentingnya data lingkungan dan data perilaku pesawat sebagai informasi referensi dalam melakukan pengamatan foto udara, maka dirancang sebuah sistem yang mampu mengintegrasikan dan menyimpan data-data lingkungan yang diperoleh dari pembacaan perangkat ADAHRS (Air Data, Attitude and Heading Reference System) ke dalam metadata foto udara dengan menggunakan software Exiftool sebagai pemroses utama, sehingga memudahkan bagi pengamat dalam melihat kembali data-data tersebut sewaktu-waktu. Selain itu, dengan adanya sistem ini diharapkan dapat menjadi alternatif pilihan dalam melakukan pengamatan foto udara dengan berbagai jenis kamera digital yang digunakan.

\section{METODE PENELITIAN}

\subsection{Analisa Kebutuhan Sistem}

Sistem yang dibuat dalam penelitian ini merupakan suatu sistem yang mampu mengintegrasikan data ADAHRS ke dalam metadata foto. Perangkat keras yang digunakan dalam penelitian ini yaitu UAV berupa fixed-wing jenis bixler yang telah terpasang kamera mobius dan perangkat ADAHRS. Kamera mobius digunakan untuk pengambilan citra foto, sedangkan perangkat ADAHRS digunakan untuk pengambilan data-data lingkungan maupun data perilaku pesawat. ADAHRS yang digunakan dalam penelitian ini merupakan hasil penelitian yang dilakukan oleh [7]. Selain itu, digunakan pula sebuah notebook yang telah dilengkapi pustaka perl dan antarmuka baris perintah ExifTool 9.75 sebagai pengolah data untuk proses integrasi data ADAHRS dengan metadata foto udara. ExifTool yang digunakan merupakan perangkat lunak yang dirancang khusus untuk membaca, menulis, dan mengedit informasi metadata dalam berbagai jenis file, salah satunya yaitu file gambar [8].

Data yang dikumpulkan sebagai objek penelitian berupa citra foto dan data ADAHRS. Citra foto yang digunakan berasal dari hasil pemotretan udara menggunakan kamera mobius

IJEIS Vol. 6, No. 2, October 2016 : 163 - 174 
yang terpasang pada UAV. Data ADAHRS diperoleh dari perangkat ADAHRS yang juga terpasang pada UAV saat pengambilan citra. Kedua perangkat tersebut harus dipasang dalam satu UAV yang sama dan setelah setiap kali melakukan pengambilan data, data foto dan data ADAHRS yang diperoleh harus segera dipindahkan dan disimpan ke sebuah folder penyimpanan yang berbeda di notebook sebagai pengolah data, dengan tujuan untuk menghindari tertukarnya data satu dengan data lainnya. Untuk data foto yang diambil berkisar 100 hingga 500 buah foto pada setiap resolusi foto yang berbeda.

Hasil pengambilan data foto dan data ADAHRS kemudian akan dijadikan sebagai masukan sistem. Metadata foto yang menjadi masukan sistem meliputi tag SourceFile dan DateTimeOriginal yang diekstraksi dan disimpan dalam file format CSV dengan menggunakan ExifTool. Data ADAHRS yang menjadi masukan sistem meliputi data tanggal, waktu, kecepatan udara GPS latitude, GPS longitude, ketinggian, tekanan udara, suhu, roll, pitch dan yaw, dimana keseluruhan data tersebut disimpan dalam file format CSV. Hasil pengolahan data pada sistem berupa foto yang telah diperbarui metadatanya, yang telah dilengkapi dengan data ADAHRS serta diketahui lama waktu setiap proses dan total waktu keseluruhan proses.

\subsection{Rancangan Sistem Integrasi Metadata Foto Udara dan Data ADAHRS}

Rancangan sistem integrasi metadata foto udara dengan data sistem ADAHRS merupakan perancangan tahapan-tahapan yang dilakukan untuk menggabungkan data sensor ADAHRS yang diperoleh bersamaan saat pengambilan foto udara dengan menggunakan UAV, kemudian mencari kesamaan pada datestamp dan timestamp antara data sensor dan foto udara, dan selanjutnya dilakukan integrasi data sensor ke dalam metadata EXIF foto tersebut. EXIF merupakan embedded metadata dalam gambar oleh sebuah kamera saat gambar pertama kali dan standar metadata foto yang paling umum digunakan oleh kamera digital diambil [9].

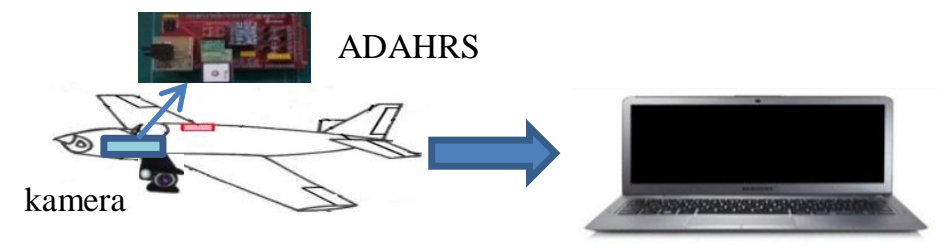

Gambar 1 Skema rancangan sistem integrasi metadata foto dengan data ADAHRS

Gambar 1 menjelaskan bahwa sistem terdiri dari tahap pengambilan foto udara dan data ADAHRS serta proses pengintegrasian data sensor ke dalam metadata EXIF foto udara tersebut. Proses pengambilan foto udara dilakukan dengan menggunakan kamera mobius, yang dipasang pada UAV dengan posisi lensa kamera menghadap ke arah permukaan wilayah. Sedangkan proses pengambilan data ADAHRS dilakukan dengan menggunakan ADAHRS yang dipasang pada UAV, yang kemudian data disimpan dengan format file CSV (Comma Separated Value) dalam data logger berupa SD Card. Mekanisme sinkronisasi tanggal dan waktu antara kamera dengan ADAHRS sebelum terbang dilakukan dengan cara menyesuaikan tanggal (datestamp) dan waktu (timestamp) yang terdapat pada kedua perangkat tersebut dengan Waktu Indonesia Barat (GMT+7) yang dapat dilihat pada notebook, yang telah disinkronisasikan dengan waktu Indonesia berdasarkan waktu internasional (UTC).

Tahap selanjutnya adalah proses pengintegrasian data ADAHRS dengan metadata EXIF foto udara dengan menggunakan notebook. Tahap ini menggunakan pustaka perl dan aplikasi baris perintah ExifTool 9.75 yang disertakan pada program berbasis shell script. Proses pengintegrasian data ini dilakukan secara terpisah (tidak real-time), sehingga untuk mendapatkan hasil gambar dari foto udara dan data ADAHRS harus dilakukan pendaratan terlebih dahulu. Setelah melakukan pendaratan, gambar dan data ADAHRS yang diperoleh dimasukkan ke notebook dan selanjutnya dilakukan proses integrasi. 


\subsection{Deskripsi Sistem}

Sistem secara menyeluruh yang akan dibangun merupakan sebuah sistem yang digunakan untuk melakukan pengintegrasian data ADAHRS ke dalam metadata EXIF foto, seperti yang ditunjukkan oleh Gambar 2, yang merupakan diagram blok rancangan sistem secara keseluruhan. Ruang lingkup kerja dalam penelitian ini berada pada perangkat lunak, yaitu sistem integrasi metadata foto dari hasil pemotretan udara dengan data ADAHRS. Proses pengambilan foto dan data ADAHRS dengan menggunakan UAV. Proses pengambilan kedua data tersebut dilakukan secara bersamaan. Hasil dari pemotretan udara disimpan dalam sebuah SD card pada kamera, begitu pula data ADAHRS yang diperoleh disimpan dalam data logger.

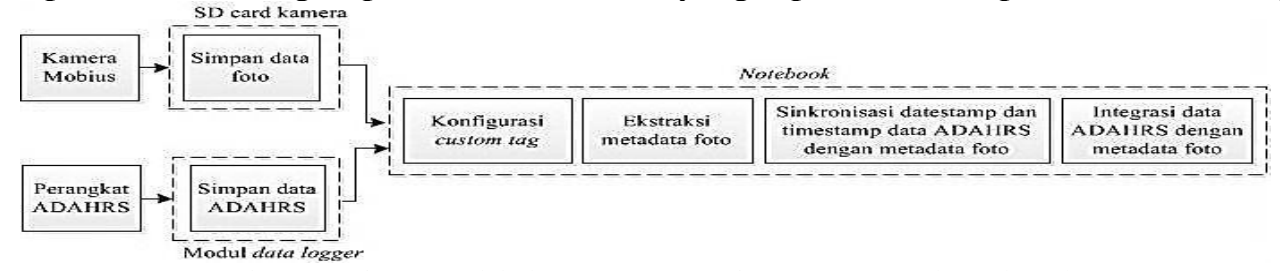

Gambar 2 Diagram blok rancangan sistem secara keseluruhan

Gambar yang diperoleh dari pemotretan udara kemudian dikonfigurasikan dengan sebuah file konfigurasi menggunakan ExifTool, dengan tujuan menanam custom tag baru yang telah disesuaikan dengan data ADAHRS ke dalam metadata foto. Selanjutnya adalah ekstraksi metadata foto dan disimpan dalam format CSV, untuk memperoleh metadata foto dan kemudian dilakukan proses sinkronisasi dengan membandingkan datestamp dan timestamp antara metadata foto dan data ADAHRS. Apabila terdapat kesamaan datestamp dan timestamp pada keduanya, maka secara otomatis data ADAHRS akan tergabung dengan file ekstraksi metadata foto dan membentuk sebuah file baru berformat CSV, dimana file tersebut berisi nama file foto diikuti dengan data-data ADAHRS yang bersangkutan. Tahap terakhir yang dilakukan adalah proses pengintegrasian data ADAHRS ke dalam metadata foto. Proses ini dilakukan dengan cara memasukkan file CSV hasil sinkronisasi sebelumnya ke dalam metadata foto dengan menggunakan ExifTool. Proses secara keseluruhan ini dijelaskan dalam Gambar 3.

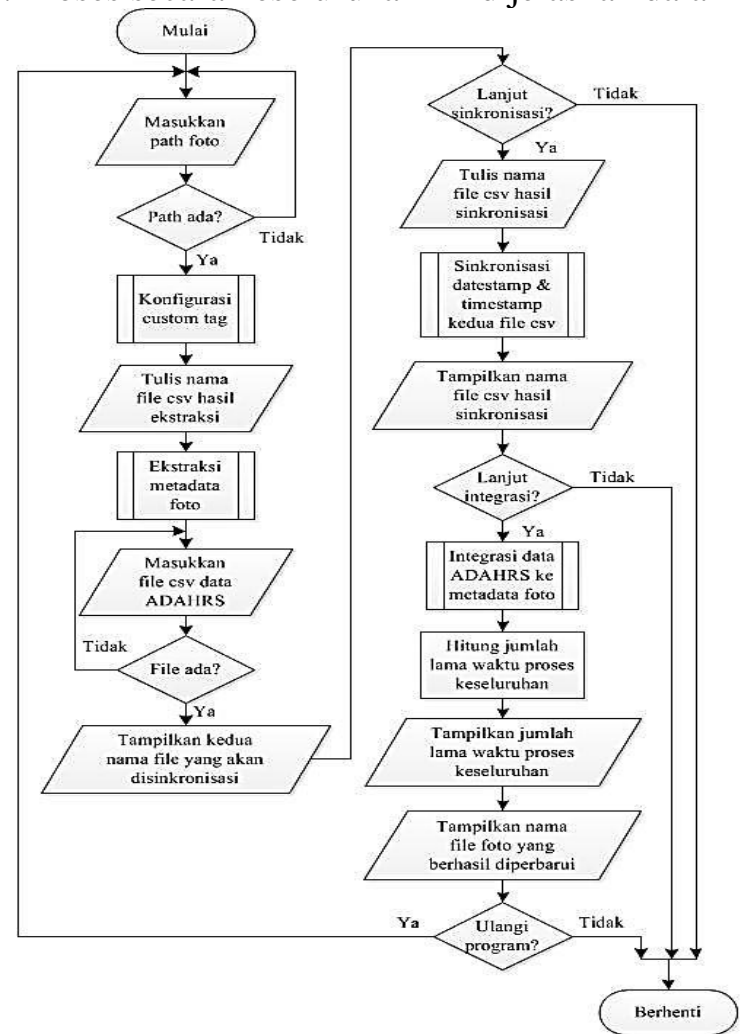

Gambar 3 Diagram alir sistem integrasi metadata foto dan data ADAHRS

IJEIS Vol. 6, No. 2, October 2016 : $163-174$ 


\subsection{Implementasi}

Implementasi perangkat lunak meliputi program utama sistem integrasi metadata foto udara dengan data ADAHRS, program penyesuaian tanggal dan waktu pada perangkat ADAHRS serta program sistem perekam data ADAHRS. Implementasi program utama sistem tersebut terdiri dari empat bagian, yaitu konfigurasi custom tag baru, ekstraksi metadata foto, sinkronisasi metadata foto dengan data ADAHRS, serta integrasi data ADAHRS ke dalam metadata foto. Pembuatan program utama sistem ini dilakukan dengan menggunakan Exiftool 9.75, yang merupakan sebuah pustaka berbasis perl yang telah dilengkapi dengan fitur command-line terminal. Sedangkan implementasi pembuatan program penyesuaian tanggal dan waktu pada perangkat ADAHRS serta program sistem perekam data ADAHRS dilakukan dengan menggunakan software compiler Arduino IDE 1.5.8, berbasis bahasa pemrograman $\mathrm{C}++$. Program penyesuaian tanggal dan waktu pada perangkat ADAHRS dibuat dengan tujuan untuk mendapatkan tanggal dan waktu yang sesuai dengan Waktu Indonesia Barat (GMT+7). Data-data lingkungan yang diperoleh dari perangkat ADAHRS kemudian akan direkam atau disimpan dalam data logger untuk dianalisa dan selanjutnya diintegrasikan dengan metadata foto yang diperoleh dari hasil pemotretan udara.

Implementasi perangkat keras terdiri dari perangkat ADAHRS, modul RTC, modul data logger dan kamera mobius seperti yang ditunjukkan pada Gambar 3. Perangkat keras tersebut dipasang pada pada pesawat bixler. Pesawat Bixler yang digunakan adalah tipe RTF (Ready To Fly), sehingga semua komponen sudah tersedia dan tidak membutuhkan waktu lama untuk dirakit dan siap terbang untuk pengambilan data.
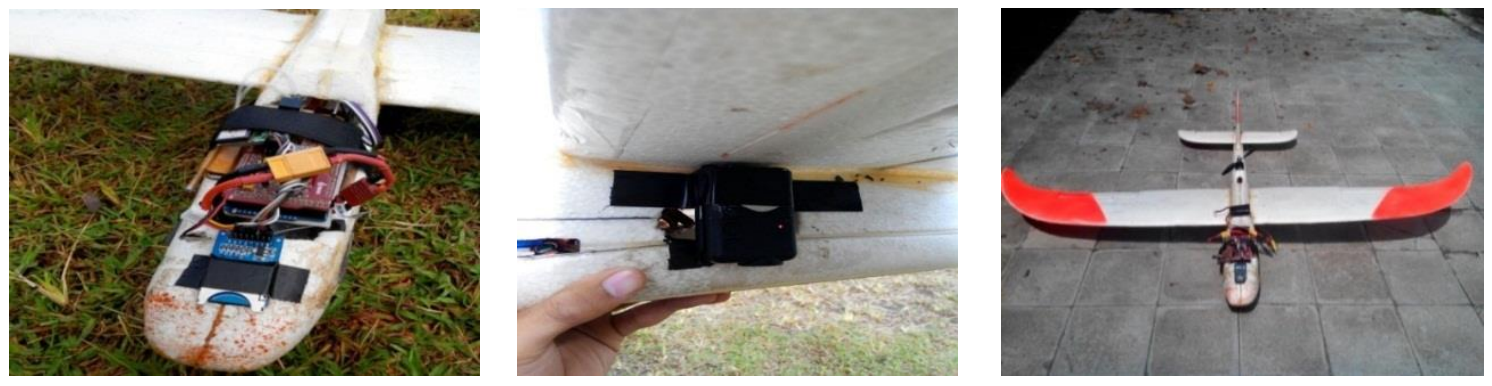

Gambar 3 Implementasi perangkat keras

\section{HASIL DAN PEMBAHASAN}

\subsection{Pengujian Variasi Resolusi Foto dan Jumlah Foto}

Pengujian ini dilakukan untuk mengetahui pengaruh resolusi foto dan jumlah foto terhadap lama waktu yang ditempuh oleh setiap proses yang terdapat dalam sistem integrasi ini. Pada sistem ini terdapat empat proses penting, yaitu konfigurasi custom tag, ekstraksi metadata foto, sinkronisasi datestamp dan timestamp metadata foto dengan ADAHRS serta integrasi data ADAHRS dengan metadata foto.

Untuk menghitung lama waktu pemrosesan yang terjadi pada setiap proses yang terdapat dalam sistem ini, maka dibutuhkan sebuah waktu komputasi. Waktu komputasi yang digunakan dalam sistem ini merupakan waktu komputasi berdasarkan waktu yang terdapat dalam notebook sebagai pengolah data. Karena perangkat keras yang terdapat dalam komputer akan berpengaruh terhadap waktu pemrosesan pada keseluruhan proses yang dilakukan oleh sistem.

Resolusi foto yang digunakan pada pengujian ini adalah 2304 piksel x 1536 piksel, 1920 piksel x 1080 piksel, 1280 piksel x 720 piksel, dan 848 piksel x 480 piksel. Variasi jumlah foto yang akan diujikan pada keempat resolusi foto tersebut adalah antara 100 hingga 500 buah foto, dengan jangkauan 100 buah foto di setiap variasinya. Hasil pengujian pengaruh resolusi foto dan jumlah foto terhadap lama waktu yang ditempuh oleh setiap proses yang terdapat pada 
sistem integrasi metadata foto udara dengan data ADAHRS dapat dilihat pada Tabel 1, Tabel 2 , Tabel 3, dan Tabel 4.

\subsubsection{Konfigurasi Custom Tag}

Konfigurasi custom tag merupakan proses awal dalam sistem integrasi ini. Proses ini mempunyai peranan penting dalam sistem integrasi, dimana dilakukan penanaman atau penambahan custom tag untuk data ADAHRS yang akan diintegrasikan dengan metadata foto nantinya.

Tabel 1 Hasil pengujian variasi resolusi foto dan jumlah foto pada proses konfigurasi custom tag

\begin{tabular}{|c|c|c|c|c|c|}
\hline \multirow{2}{*}{$\begin{array}{c}\text { Jumlah } \\
\text { Foto }\end{array}$} & \multicolumn{3}{|c|}{ Waktu Pemrosesan (detik) } & \multirow{2}{*}{ Waktu Rerata (detik) } \\
\cline { 2 - 5 } & $2304 \times 1536$ & $1920 \times 1080$ & $1280 \times 720$ & $848 \times 480$ & 1,206 \\
\hline 100 & 1,209 & 1,201 & 1,209 & 1,205 & 2,324 \\
\hline 200 & 2,316 & 2,320 & 2,325 & 2,335 & 3,435 \\
\hline 300 & 3,439 & 3,439 & 3,432 & 3,429 & 4,552 \\
\hline 400 & 4,559 & 4,548 & 4,552 & 4,549 & 5,658 \\
\hline 500 & 5,671 & 5,658 & 5,661 & 5,642 & \\
\hline
\end{tabular}

Berdasarkan hasil pengujian pada Tabel 1, dapat dilihat bahwa terdapat selisih nilai milidetik pada waktu pemrosesan yang terjadi pada pengujian data dari satu resolusi foto dengan resolusi foto lainnya, dengan jumlah foto yang sama. Hal tersebut dapat dipengaruhi oleh proses buffer (proses penyimpanan data saat data dipindahkan) yang terjadi di dalam disk cache (bagian dari memori utama yang menjembatani disk dan CPU) pada notebook sebagai pengolah data. Secara keseluruhan dapat diketahui bahwa variasi resolusi foto yang dikonfigurasikan tidak berpengaruh terhadap waktu pemrosesan pada konfigurasi custom tag tersebut. Hal ini dikarenakan proses konfigurasi ini hanya memroses metadata EXIF fotonya saja, tanpa melihat berapa besar ukuran foto tersebut, dimana standar format metadata EXIF yang terdapat pada berbagai resolusi foto adalah sama. Namun, variasi jumlah foto yang dikonfigurasikan memiliki pengaruh terhadap lama waktu pemrosesan. Semakin banyak jumlah fotonya, maka akan semakin lama pula waktu pemrosesannya.

Selain itu, dari data hasil pengujian tersebut dapat pula diketahui perkiraan pola waktu pemrosesan yang dibutuhkan untuk memroses foto dengan variasi resolusi foto maupun jumlah foto yang lebih banyak. Hal ini ditunjukkan oleh waktu rerata yang dihasilkan dari pengujian tersebut, yakni untuk memroses 4 (empat) resolusi foto yang berbeda diperoleh waktu rerata sebesar 1,206 detik untuk 100 buah foto, 2,324 detik untuk 200 buah foto, 3,435 detik untuk 300 buah foto, 4,552 detik untuk 400 buah foto dan 5,658 detik untuk 500 buah foto.

\subsubsection{Ekstraksi Metadata Foto}

Pada proses ini dilakukan ekstraksi metadata foto yang meliputi data SourceFile dan DateTimeOriginal, yang selanjutnya ditulis dan disimpan dalam file CSV dengan nama file CSV yang ditentukan sendiri oleh user.

Tabel 2 Hasil pengujian variasi resolusi foto dan jumlah foto proses ekstraksi metadata foto

\begin{tabular}{|c|c|c|c|c|c|}
\hline \multirow{2}{*}{$\begin{array}{c}\text { Jumlah } \\
\text { Foto }\end{array}$} & \multicolumn{3}{|c|}{ Waktu Pemrosesan (detik) } & \multirow{2}{*}{$\begin{array}{c}\text { Waktu Rerata } \\
\text { (detik) }\end{array}$} \\
\cline { 2 - 4 } & $2304 \times 1536$ & $1920 \times 1080$ & $1280 \times 720$ & $848 \times 480$ & 0,840 \\
\hline 100 & 0,834 & 0,845 & 0,841 & 0,840 & 1,597 \\
\hline 200 & 1,610 & 1,606 & 1,585 & 1,586 & 2,361 \\
\hline 300 & 2,365 & 2,336 & 2,367 & 2,376 & 3,079 \\
\hline 400 & 3,065 & 3,072 & 3,099 & 3,082 & 3,864 \\
\hline 500 & 3,865 & 3,839 & 3,884 & 3,870 & \\
\hline
\end{tabular}

Berdasarkan hasil pengujian pada Tabel 2, dapat dilihat bahwa terdapat selisih nilai milidetik pada waktu pemrosesan yang terjadi pada pengujian data dari satu resolusi foto dengan resolusi foto lainnya, dengan jumlah foto yang sama. Seperti halnya yang terjadi pada proses konfigurasi, hal tersebut juga dipengaruhi oleh proses buffer (proses penyimpanan data 
saat data dipindahkan) yang terjadi di dalam disk cache (bagian dari memori utama yang menjembatani disk dan CPU) pada notebook sebagai pengolah data. Selain itu, pada proses ini juga dapat diketahui bahwa variasi resolusi foto tidak berpengaruh terhadap waktu pemrosesan pada proses ekstraksi metadata foto tersebut. Hal ini dikarenakan proses ini hanya mengolah metadata EXIF fotonya saja untuk diekstraksi, ditulis dan disimpan dalam file CSV, tanpa melihat berapa besar ukuran foto tersebut. Namun, banyaknya jumlah foto yang diolah dapat mempengaruhi lama waktu pemrosesan. Semakin banyak foto yang diolah, maka semakin lama pula waktu pemrosesannya.

Dengan adanya data hasil pengujian ini, dapat diketahui perkiraan pola waktu pemrosesan yang dibutuhkan untuk mengekstraksi metadata foto dengan variasi resolusi maupun jumlah foto yang lebih banyak. Hal ini ditunjukkan oleh waktu rerata yang dihasilkan dari pengujian tersebut, yakni untuk mengekstraksi metadata foto dari 4 (empat) resolusi foto yang berbeda diperoleh waktu rerata sebesar 0,840 detik untuk 100 buah foto, 1,597 detik untuk 200 buah foto, 2,361 detik untuk 300 buah foto, 3,079 detik untuk 400 buah foto dan 3,864 detik untuk 500 buah foto. Pembacaan data hasil ekstraksi metadata foto dalam file CSV dapat dilihat pada Gambar 4. Data SourceFile menunjukkan path lengkap atau lokasi file foto yang bersangkutan, sedangkan DateTimeOriginal menunjukkan tanggal dan waktu pembuatan dan pengambilan foto dilakukan. Kedua data tersebut mempunyai peran penting dalam proses yang akan terjadi selanjutnya.

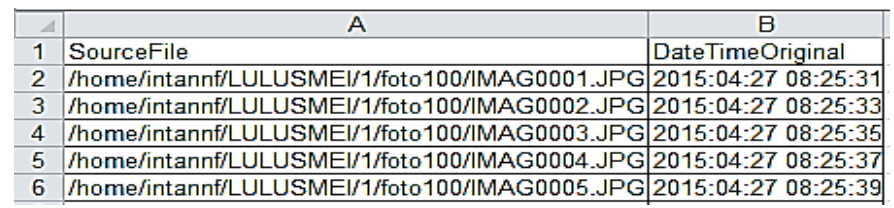

Gambar 4 Data hasil ekstraksi metadata foto

\subsubsection{Sinkronisasi Metadata Foto dan Data ADAHRS}

Proses sinkronisasi ini dilakukan dengan cara membandingkan datestamp dan timestamp yang terdapat pada file CSV hasil ekstraksi metadata foto dengan file CSV hasil perekaman data ADAHRS.

Tabel 3 Hasil pengujian variasi resolusi foto dan jumlah foto pada proses sinkronisasi datestamp dan timestamp

\begin{tabular}{|c|c|c|c|c|}
\hline $\begin{array}{l}\text { Jumlah } \\
\text { Foto }\end{array}$ & Resolusi Foto & $\begin{array}{c}\text { Jumlah Baris Data } \\
\text { ADAHRS }\end{array}$ & Waktu Pemrosesan (detik) & Waktu Rerata (detik) \\
\hline \multirow{4}{*}{100} & $2304 \times 1536$ & 1617 & 0,035 & \multirow{4}{*}{0,037} \\
\hline & $1920 \times 1080$ & 1671 & 0,036 & \\
\hline & $1280 \times 720$ & 2298 & 0,039 & \\
\hline & $848 \times 480$ & 1831 & 0,037 & \\
\hline \multirow{4}{*}{200} & $2304 \times 1536$ & 2680 & 0,054 & \multirow{4}{*}{0,052} \\
\hline & $1920 \times 1080$ & 2724 & 0,051 & \\
\hline & $1280 \times 720$ & 3949 & 0,056 & \\
\hline & $848 \times 480$ & 2850 & 0,047 & \\
\hline \multirow{4}{*}{300} & $2304 \times 1536$ & 3745 & 0,053 & \multirow{4}{*}{0,062} \\
\hline & $1920 \times 1080$ & 3790 & 0,064 & \\
\hline & $1280 \times 720$ & 4331 & 0,065 & \\
\hline & $848 \times 480$ & 3879 & 0,067 & \\
\hline \multirow[t]{4}{*}{400} & $2304 \times 1536$ & 4808 & 0,069 & \multirow[t]{4}{*}{0,072} \\
\hline & $1920 \times 1080$ & 4854 & 0,073 & \\
\hline & $1280 \times 720$ & 5349 & 0,074 & \\
\hline & $848 \times 480$ & 4890 & 0,073 & \\
\hline \multirow[t]{4}{*}{500} & $2304 \times 1536$ & 5883 & 0,090 & \multirow[t]{4}{*}{0,083} \\
\hline & $1920 \times 1080$ & 5904 & 0,077 & \\
\hline & $1280 \times 720$ & 6370 & 0,086 & \\
\hline & $848 \times 480$ & 5911 & 0,080 & \\
\hline
\end{tabular}


Pada pengujian ini, data yang diujikan adalah file CSV dari metadata foto dengan file CSV dari data ADAHRS. Data ADAHRS tersebut diambil secara bersamaan pada saat pengambilan data foto. Proses ini tidak melibatkan foto untuk diolah, melainkan hanya membutuhkan metadata fotonya saja yang telah tersimpan dalam file CSV, sehingga dapat diketahui bahwa resolusi foto tidak berpengaruh terhadap waktu pemrosesan sinkronisasi datestamp dan timestamp tersebut. Pada proses ini banyaknya metadata foto yang diproses adalah sama dengan banyaknya jumlah foto.

Berdasarkan hasil pengujian pada Tabel 3, dapat dilihat bahwa banyaknya data ADAHRS juga tidak berpengaruh terhadap lama waktu pemrosesan. Hal ini dapat dilihat jelas dari data ADAHRS pada resolusi foto $1280 \times 720$ yang mempunyai data jauh lebih banyak bila dibandingkan data yang dimiliki oleh ketiga resolusi foto lainnya pada setiap variasi jumlah foto yang diujikan. Walaupun data ADAHRS pada resolusi tersebut lebih banyak yang akan disinkronisasikan/dibandingkan dengan metadata foto, namun waktu pemrosesannya tidak berbeda jauh bila dibandingkan waktu pemrosesan lainnya, hanya memiliki selisih dalam hitungan milidetik saja. Hal ini dapat disebabkan oleh pengaruh proses buffer (proses penyimpanan data saat data dipindahkan) yang terjadi di dalam disk cache (bagian dari memori utama yang menjembatani disk dan CPU) pada notebook sebagai pengolah data.

Dari data pengujian tersebut, dapat diketahui bahwa jumlah foto/jumlah metadata foto berpengaruh terhadap lamanya waktu pemrosesan. Semakin banyak metadata foto yang akan disinkronisasikan dengan data ADAHRS, maka akan semakin lama pula waktu pemrosesannya. Dengan adanya data hasil pengujian ini, dapat pula diketahui perkiraan pola waktu pemrosesan yang dibutuhkan untuk proses sinkronisasi datestamp dan timestamp foto dengan variasi resolusi foto maupun jumlah foto yang lebih banyak. Hal ini ditunjukkan oleh waktu rerata yang dihasilkan dari pengujian tersebut, yaitu untuk sinkronisasi data ADAHRS dengan metadata foto dari 4 (empat) resolusi foto yang berbeda diperoleh waktu rerata sebesar 0,037 detik untuk 100 buah foto, 0,052 detik untuk 200 buah foto, 0,062 detik untuk 300 buah foto, 0,077 detik untuk 400 buah foto dan 0,083 detik untuk 500 buah foto. Hasil dari proses sinkronisasi merupakan file CSV baru berupa data gabungan dari kedua file CSV tersebut, yang meliputi data SourceFile, AirSpeed, GPSLatitude, GPSLongitude, Temperature, Pressure, Altitude, Roll, Pitch, dan Yaw seperti yang ditunjukkan pada Gambar 5.

\begin{tabular}{|c|c|c|c|c|c|c|c|c|c|c|}
\hline & A & B & C & D & $E$ & $\mathrm{~F}$ & G & $\mathrm{H}$ & 1 & $\mathrm{~J}$ \\
\hline 1 & SourceFile & Airspeed & GPSLatitude & GPSLongitude & Temperature & Pressure & Altitude & Roll & Pitch & Yaw \\
\hline 2 & /home/intannf/LULUSMEI/1/foto100/IMAG0001.JPG & 1,62 & $-7,77148$ & 110,37795 & 31,37 & 995,8 & 155,04 & 207,51 & 173,36 & 125,54 \\
\hline 3 & /home/intannf/LULUSMEI/1/foto100/IMAG0002.JPG & 1,81 & $-7,77148$ & 110,37795 & 31,4 & 995,56 & 157,18 & 204,08 & 175,76 & 127,74 \\
\hline 4 & /home/intannf/LULUSMEI/1/foto100/IMAG0003.JPG & 1,62 & $-7,77148$ & 110,37795 & 31,4 & 995,01 & 162,17 & 199,88 & 164,73 & 176,59 \\
\hline 5 & /home/intannf/LULUSMEI/1/foto100/IMAG0004.JPG & 2,29 & $-7,77148$ & 110,37795 & 31,29 & 993,85 & 172,49 & 186,1 & 181,97 & 218,2 \\
\hline 6 & /home/intannf/LULUSMEI/1/foto100/IMAG0005.JPG & 1,99 & $-7,77148$ & 110,37795 & 31,43 & 993,93 & 171,9 & 182,49 & 214,11 & 309,12 \\
\hline
\end{tabular}

Gambar 5 Data hasil sinkronisasi datestamp dan timestamp

\subsubsection{Integrasi Data ADAHRS dengan Metadata Foto}

Pada proses ini, data hasil proses sinkronisasi yang meliputi data SourceFile foto dan data ADAHRS akan diintegrasikan dan ditambahkan ke dalam metadata foto yang bersangkutan secara otomatis, mengingat metadata foto merupakan embedded metadata yang bersifat deskriptif, sehingga proses input data dapat dilakukan secara otomatis [10].

Tabel 4 Hasil pengujian variasi resolusi foto dan jumlah foto pada proses integrasi data

ADAHRS dengan metadata foto

\begin{tabular}{|c|c|c|c|c|c|}
\hline \multirow{2}{*}{$\begin{array}{c}\text { Jumlah } \\
\text { Foto }\end{array}$} & \multicolumn{3}{|c|}{ Waktu Pemrosesan (detik) } & \multirow{2}{*}{$\begin{array}{c}\text { Waktu Rerata } \\
\text { (detik) }\end{array}$} \\
\cline { 2 - 5 } & $2304 \times 1536$ & $1920 \times 1080$ & $1280 \times 720$ & $848 \times 480$ & 1,853 \\
\hline 100 & 2,007 & 1,854 & 1,801 & 1,749 & 3,481 \\
\hline 200 & 3,898 & 3,443 & 3,336 & 3,248 & 5,298 \\
\hline 300 & 6,427 & 5,085 & 4,922 & 4,759 & 7,037 \\
\hline 400 & 8,668 & 6,673 & 6,481 & 6,325 & 8,855 \\
\hline 500 & 10,624 & 8,945 & 8,027 & 7,825 & \\
\hline
\end{tabular}

IJEIS Vol. 6, No. 2, October 2016 : $163-174$ 
Berdasarkan Tabel 4, dapat diketahui bahwa resolusi foto dan jumlah foto yang diujikan memiliki pengaruh terhadap lama waktu yang dibutuhkan untuk melakukan proses integrasi antara data ADAHRS dengan metadata foto. Semakin besar resolusi foto dan semakin banyak jumlah foto yang akan ditambahkan nilai metadatanya, maka akan semakin lama pula waktu pemrosesan yang terjadi. Hal ini dikarenakan pengaruh buffer yang terjadi akibat besarnya ukuran foto. Semakin besar resolusi foto yang digunakan, maka akan semakin besar pula ukuran foto yang dihasilkan, sehingga menyebabkan waktu yang dibutuhkan untuk proses buffer semakin lama. Karena dalam hal ini proses tersebut akan membaca file terlebih dahulu sebelum menulis atau menambahkan nilai pada metadata foto yang bersangkutan.

Dari data hasil pengujian tersebut, dapat diketahui waktu pemrosesan yang perkiraan pola waktu pemrosesan yang dibutuhkan untuk proses integrasi data ADAHRS dengan metadata foto, seperti yang ditunjukkan oleh waktu rerata yang dihasilkan dari pengujian tersebut, yaitu untuk integrasi data ADAHRS dengan metadata foto dari 4 (empat) resolusi foto yang berbeda diperoleh waktu rerata sebesar 1,853 detik untuk 100 buah foto, 3,481 detik untuk 200 buah foto, 5,298 detik untuk 300 buah foto, 7,037 detik untuk 400 buah foto dan 8,855 detik untuk 500 buah foto.

Setelah selesai dilakukan penambahan metadata pada foto, secara otomatis sistem akan membuat backup file dari foto yang telah berhasil diperbarui metadata. Backup file tersebut berupa foto asli dari foto yang telah diperbarui metadatanya. Foto yang berhasil diperbarui metadatanya akan mempunyai nama file yang sama seperti sebelumnya (tetap), sedangkan pada backup file foto yang asli akan ditambahkan tulisan _original setelah akhir nama file tersebut, seperti yang ditunjukkan pada Gambar 6. Contoh hasil metadata foto yang telah diperbarui dapat dilihat pada Gambar 7.

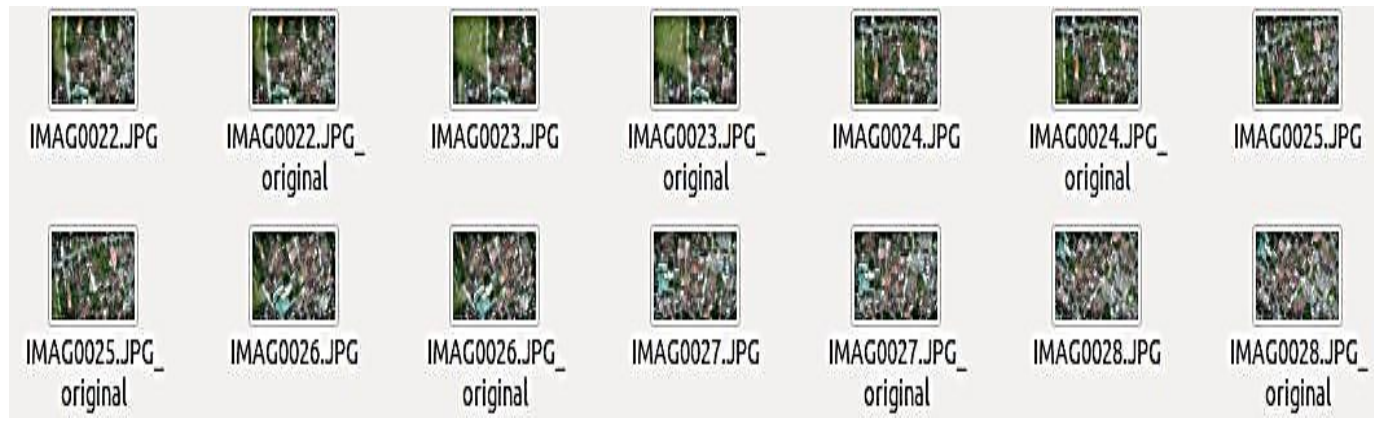

Gambar 6 Foto yang telah diperbarui metadatanya beserta backup file-nya 


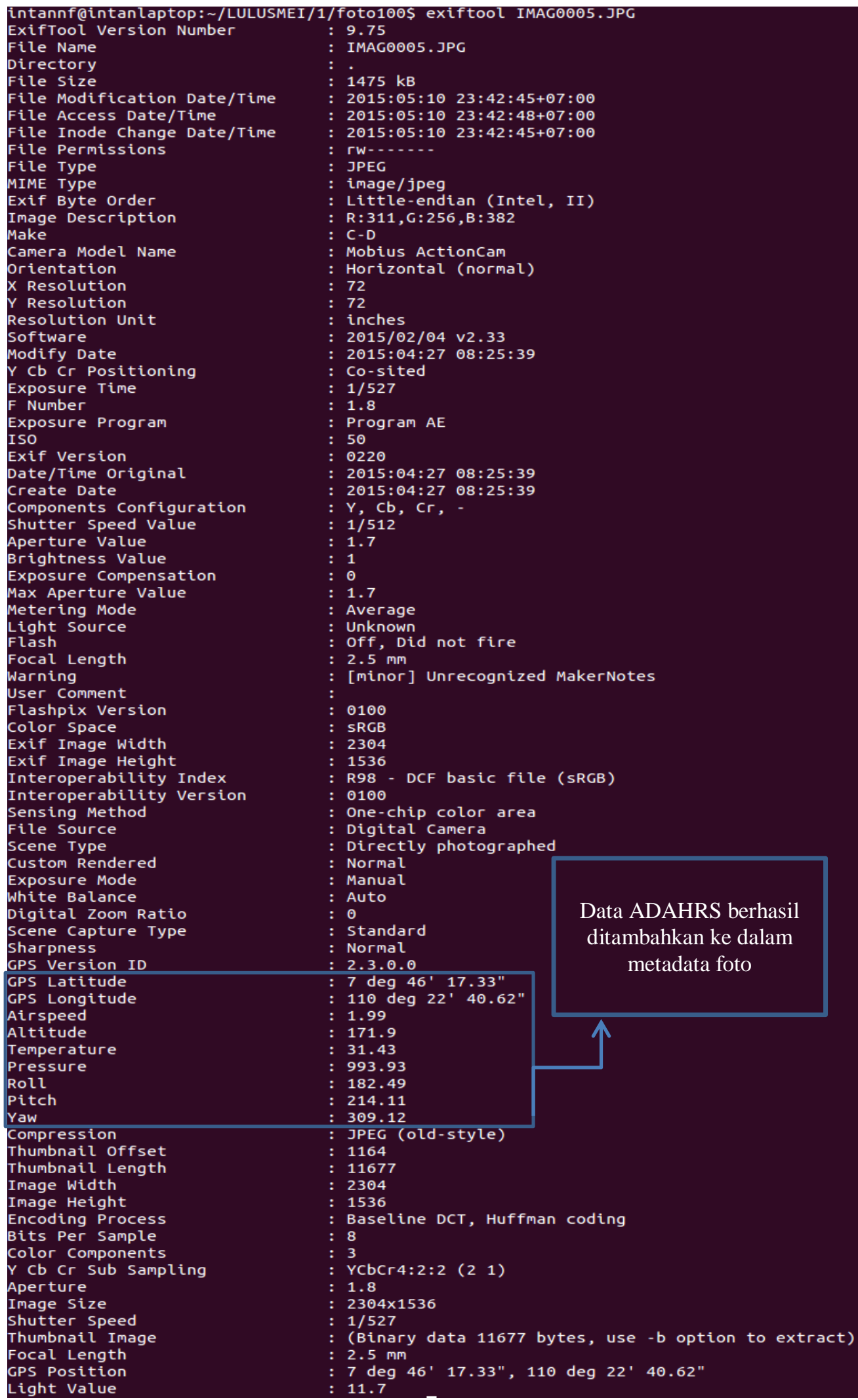

Gambar 7 Metadata foto setelah diintegrasi

IJEIS Vol. 6, No. 2, October 2016 : 163 - 174 


\section{KESIMPULAN}

Berdasarkan hasil pengamatan, pengujian, dan analisis pada hasil yang diperoleh, kesimpulan yang dapat diambil adalah sebagai berikut :

1. Sistem yang dibuat mampu mengintegrasikan data ADAHRS pada beberapa variasi jumlah foto dengan beberapa variasi resolusi foto. Jumlah foto yang diujikan adalah 100-500 buah foto pada setiap resolusi yang diujikan, dengan jangkauan 100 buah foto tiap variasinya. Sedangkan resolusi foto yang diujikan yakni 2304 piksel x 1536 piksel, 1920 piksel x 1080 piksel, 1280 piksel x 720 piksel, dan 848 piksel x 480 piksel.

2. Data ADAHRS yaitu koordinat GPS (latitude dan longitude), kecepatan udara, ketinggian, suhu, tekanan, dan data perilaku pesawat (roll, pitch dan yaw) berhasil ditambahkan ke dalam metadata foto.

3. Sistem ini mampu membuat backup file dari foto yang berhasil diperbarui metadatanya secara otomatis, sehingga tetap menjaga dan menyimpan keaslian metadata dari sumber foto yang asli.

4. Resolusi foto hanya berpengaruh terhadap lama waktu pemrosesan yang terjadi proses integrasi data ADAHRS dengan metadata foto.

5. Jumlah foto berpengaruh terhadap lama waktu pemrosesan yang terjadi pada keempat proses yang terdapat dalam sistem ini, yaitu proses konfigurasi custom tag, proses ekstraksi metadata foto, proses sinkronisasi datestamp dan timestamp, serta proses integrasi data ADAHRS dengan metadata foto.

6. Total rerata lamanya waktu keseluruhan proses yang dilakukan sistem pada keempat resolusi tersebut, yakni 3,936 detik untuk 100 buah foto, 7,454 detik untuk 200 buah foto, 11,156 detik untuk 300 buah foto, 14,740 detik untuk 400 buah foto dan 18,460 detik untuk 500 buah foto.

7. Waktu komputasi yang digunakan dalam sistem ini merupakan waktu komputasi berdasarkan waktu yang terdapat dalam notebook sebagai pengolah data, sehingga apabila sistem ini dijalankan pada komputer atau perangkat pengolah data lain yang mempunyai spesifikasi perangkat keras yang berbeda, maka lama waktu pemrosesan yang dibutuhkan oleh keseluruhan proses dalam sistem ini akan berbeda pula, menjadi lebih cepat maupun lebih lama dari total rerata waktu pemrosesan pada hasil pengujian tersebut.

\section{SARAN}

Untuk pengembangan lebih lanjut dalam sistem ini disarankan untuk melakukan hal sebagai berikut:

1. Sistem integrasi tidak hanya diterapkan pada format file foto JPG/JPEG saja, melainkan juga diterapkan pada format file foto lainnya.

2. Sistem yang dibuat akan lebih baik dilengkapi dengan menggunakan GUI (Graphical User Interface), bukan CLI (Command Line Interface).

3. Hendaknya sistem integrasi metadata foto udara dengan data ADAHRS ini dapat dikembangkan secara real-time, sehingga data ADAHRS dapat terintegrasi secara langsung ke dalam metadata foto pada saat pengambilan data foto dan data ADAHRS dengan menggunakan UAV.

4. Untuk menghindari tertukarnya data foto, maka perlu ditambahkan ekstraksi metadata foto berupa tag Camera Model Name dan untuk sinkronisasi data foto dengan data ADAHRS, selain datestamp dan timestamp-nya maka perlu disinkronisasikan jenis kamera (ID kamera) yang digunakan. 


\section{UCAPAN TERIMA KASIH}

Penulis mengucapkan terima kasih kepada PPKI UGM yang telah memberi dukungan finansial terhadap penelitian ini.

\section{DAFTAR PUSTAKA}

[1] Susilawati, S.S.R., 2007, Mengenal Metadata sebagai Sebuah Alat Investasi Data, Buletin Sumber Daya Geologi, Nomor 1, Volume 2.

[2] Pelski, S., 2005, Oracle interMedia User's Guide, 10g Release 2 (10.2), Oracle Corporation, Redwood City.

[3] Ireene, A., Septiana, D.A., Sujiwo, R., dan Wicaksana, I.W.S., 2008, Pendekatan Steganografi dengan LSB untuk Menggabungkan Metadata METS ke File Grafik pada Multimedia Database, Proceeding, Seminar Ilmiah Nasional Komputer dan Sistem Intelijen, Depok, 20-21 Agustus.

[4] Sutriya, D., Akbar, J.L., Zahab, N.M., Fizki, F., Mikael, Immanuel, dan Wicaksana, I.W.S., 2008, Metadata pada File Grafik sebagai Referensi untuk Menghindari Kesalahan Input, Proceeding, Seminar Ilmiah Nasional Komputer dan Sistem Intelijen, Depok, 20-21 Agustus.

[5] Li-Gu, Z., Zhi-Wei, S., dan Hao, L., 2009, Research on Integrated Metadata for Distributed CAS Appliance System, 2009 IEEE International Conference on Management and Service Center, Wuhan, 20-22 September.

[6] Kakar, P., dan Sudha, N., 2012, Authenticating Image Metadata Elements using Geolocation and Sun Direction Estimation, 2012 IEEE International Conference on Multimedia and Expo.

[7] Pratama, F.N., 2013, Sistem Referensi Air Data, Attitude, dan Heading Berbasis Arduino Due pada Pesawat Terbang Tanpa Awak, Skripsi, Universitas Gadjah Mada, Yogyakarta.

[8] Harvey, P., 2015, ExifTool Application Documentation, http://www.sno.phy.queensu.ca/ phil/exiftool/exiftool_pod.html, diakses tanggal 04 April 2015 pukul 11:27 WIB.

[9] Hackney, D., 2008, Digital Photography Metadata Overview, http://www.hackneys.com/travel/docs/metadataoverview.pdf, diakses tanggal 04 April 2015 pukul 15:09 WIB.

[10] Embedded Metadata Working Group, 2010, Basic Guidelines for Minimal Descriptive Embedded Metadata in Digital Images, http://www.digitizationguidelines.gov/guidelines/digitize-core_embedded_metadata.html, diakses tanggal 07 April 2015 pukul 12:03 WIB. 